American University Washington College of Law

Digital Commons @ American University Washington College of

Law

Articles in Law Reviews \& Other Academic Journals

Scholarship \& Research

1995

Limited Mandates and Intertwined Problems: A New Challenge for the World Bank and the IMF

Daniel D. Bradlow

Claudio Grossman

Follow this and additional works at: https://digitalcommons.wcl.american.edu/facsch_lawrev

Part of the Banking and Finance Law Commons, and the International Law Commons 


\title{
Limited Mandates and Intertwined Problems: A New Challenge for the World Bank and the IMF
}

\author{
Daniel D. Bradlow and Claudio Grossman ${ }^{7}$
}

\section{INTRODUCTION}

The sovereign states that participated in the establishment of the postSecond World War international order had a specific vision of how international organizations should function. This view was based on two premises. The first premise was that the sovereign state was the most significant actor in the international order. Consequently, only states could join and participate in the affairs of the new international organizations. Furthermore, international organizations were limited in their ability to interfere in the internal affairs of their member states. ${ }^{2}$

The second premise was that, with the exception of the United Nations, which has general powers within a constitutional framework, most of the organizations should have mandates that are limited to specific and defined sets of problems. ${ }^{3}$ The founding states expected each organization to

1. This article is based on a paper prepared for a conference on "Rethinking Bretton Woods," sponsored by the Center for Concern. The authors wish to thank Samir Desai for his excellent research assistance, and his indefatigable enthusiasm for this project.

2. See U.N. Charter art. 2, If 7; Louis Henkin, How Nations Bemave: Law and foreign Policy 17 (1968).

3. The United Nations is able to address any issue of interest to the international community. See Reparations for Injuries Suffered in the Service of the United Nations, 1949 I.C.J. 174, 179 (11 Apr.). The Organization of African Unity and the Organization of American States have similar competencies within their respective regional contexts. See Charter of the Orcanization of African Unity art. VIII, 479 U.N.T.S. 40; Charter of the Orcanization of American States (as amended 27 Feb. 1970), 2 U.S.T. 2394, T.I.A.S. No. 2361, 26 U.S.T. 607, T.I.A.S. No. 6847, art. 33. See also D.W. BowetT, THE LAW OF International Institutions 10 (1963); Henry G. Schermers, International Instirutional Law 3233 (1980). 
confine its activities to its specific responsibilities and to leave other issues to other international organizations. For example, the International Bank for Reconstruction and Development (IBRD) would deal with issues of "economic development," but would leave monetary questions to the International Monetary Fund (IMF) and health issues to the World Health Organization (WHO).

Since that time, the world has undergone such substantial change that the validity of these two premises has been called into question. The international organizations, which are based on exclusive state membership, are being challenged by the increasing number of actors on the international stage. Today, the ability of nonstate actors such as individuals, peoples, corporations, nongovernmental organizations (NGOs), and national liberation movements to influence international affairs has grown dramatically. ${ }^{4}$ Concurrently, the sovereign power of all states has declined in that, because most problems transcend national boundaries, states have a diminished ability to manage behavior within their borders. ${ }^{5}$ This means that the resolution of most problems requires collaborative efforts that involve both state and nonstate actors.

The effective functioning of international organizations with limited mandates has also been compromised by the growing complexity of the problems they face. In particular, the jurisdictional boundaries between international organizations have become blurred as the intertwining of the world's multiple problems has become more apparent.

International organizations have not adequately responded to the challenge that these developments pose: how to effectively deal with only those aspects of intertwined problems that fall within their mandates while, at the same time, avoiding ultra vires action. These organizations have not developed effective mechanisms for coordinating policies and operations in areas of shared jurisdiction. Furthermore, the decisionmaking bodies and operating rules of these organizations are still premised on the primacy of the sovereign state. ${ }^{6}$ This results in most international organizations seeking to solve the problems of the late twentieth and early twenty-first centuries with institutional arrangements that were designed for a bygone era.

The international organizations that have been most forcefully confronted with the challenges posed by these changes are the IMF and the World Bank Group (hereinafter "the Bank") (collectively the IFIs). ${ }^{7}$ This

4. See, e.g., Peter J. Spiro, New Global Communities: Non-Governmental Organizations in International Decision-Making Institutions, 18 WAsH. Q. 45 (1995).

5. See, e.g., Proceedings of the 88th Annual Meeting of the American Society of International Law: The Transformation of Sovereignty, 6-9 Apr. 1994 (1995).

6. See Bowetr, supra note 3, at 311; SCHermers, supra note 3, at 706.

7. The World Bank Group consists of the IBRD, the International Development Agency (IDA), the International Finance Corporation (IFC), the Multilateral Investment Guarantee 
paper discusses the forces that are challenging the IFIs and their responses thereto. The second part of this paper discusses the specific developments shaping the world in which the IFls must operate. Part three discusses the challenges facing the IFIs and the responses they have made to date. The last section proposes specific actions the IFIs could take in order to respond effectively to the demands of the modern world.

\section{DEVELOPMENTS THAT HAVE PRODUCED "INTERTWINED PROBLEMS"}

\section{A. Defining "Intertwined Problems"}

It is a truism that all human problems are related to each other. However, it is also true that the possibility of solving international problems is substantially diminished if all problems are treated as integrally related. It is for this reason that international organizations were given specific, but limited, mandates. The jurisdiction of each international organization was defined so that the organization could only deal with a prescribed set of problems. It was also limited to dealing with aspects of those problems having transboundary effects or international implications, in the sense that member states had determined that they needed external assistance to support their efforts to resolve the problem. Accordingly, the IBRD was established to deal with issues such as international capital flows for development, while the IMF was founded to promote exchange stability and international monetary cooperation. Other institutions were created to work on issues such as international trade, peace and security, health, and agriculture.

Since the end of the Second World War, there has been a steady expansion of the range of issues causing transboundary effects, as well as an increase in the number of issues that states are unable to solve, or even manage, in isolation from other states. Examples of these issues are poverty; environmental degradation; human rights; nuclear proliferation; financial flows; refugees; transfers of technology; the trade, labor, consumer, and tax consequences of globalized production patterns; and such criminal law problems as drug trafficking, gun control, and terrorism.

The increase in the number of internationalized problems has highlighted how intertwined these problems are, in the sense that it has become more difficult for the international community to resolve any one of these

Agency (MIGA), and the International Center for the Settlement of Investment Disputes (ICSID). The first three organizations are lending institutions and are the most relevant for the purpose of this paper. See infra $\S \Perp(B)$, for a general discussion of several post-World War II international organizations. 
issues in isolation from other issues. Thus, the IFIs cannot address the problem of poverty or the monetary problems of developing countries without considering the issues of refugees, environmental degradation, the capacity of the state to effectively and equitably manage its resources, population policy, and human rights, including the status of women, indigenous people, and minorities. ${ }^{8}$ Environmentalists cannot seek resolution of environmental problems without addressing issues of poverty, refugees, information flows, population, and even security concerns. ${ }^{9}$ Trade organizations can no longer effectively regulate trade without seeking agreement on environmental issues, labor policy, investment matters, the regulation of intellectual property (which in itself raises important cultural rights issues), and the regulation of trade in services (which also raises important monetary, financial, and immigration policy questions). ${ }^{10}$ Human

8. Worlo Bank, 1994 Worlo Bank Annual Report 36-37 (1994); Ibrahim F.I. Shihata, The World Bank in a Changinc Worlo: Selected Essays 121 (Franziska Tschofen \& Antonio R. Parra eds., 1991); Katarina Tomasevski, Development Aid and Human Rights Revisited 189-207 (1993) (targeting women with development aid); Worlo Bank, Enhancing Women's Participation in ECONOMIC Development (1994); Review of Further Developments in Fields with Which the Sub-Commission has been Concerned, Human Rights and the Environment, Preliminary report by Mrs. Fatma Zohra Ksentini, Special Rapporteur, pursuant to Sub-Commission resolutions 1990/7 and 1990/27, Commission on Human Rights, Sub-Commission on Prevention of Discrimination and Protection of Minorities, 43rd Sess., Provisional Agenda Item 4, at 8, U.N. Doc. E/CN.4/Sub.2/1991/8 (1991).

9. Preparations for the United Nations Conference on Environment and Development on the Basis of General Assembly Resolution 44/228 and Taking into Account Other Relevant General Assembly Resolutions: Cross-Sectoral Issues; Combating poverty, changing consumption patterns, demographic dynamics and sustainability (Section I, Chapters 2, 3 and 4 of Agenda 21); Report of the Secretary-Ceneral of the Conference, Preparatory Committee for the United Nations Conference on Environment and Development, 4th Sess., Provisional Agenda Item 2(c), qf 14, U.N. Doc. A/CONF.151/PC100/ Add. 2 (1992); Report of the United Nations Conference on Environment and Development (Rio de Janeiro, 3-14 June 1992), United Nations Conference on Environment and Development, ๆ ๆ 34.11, 34.18, U.N. Doc. A/CONF.151/26 (Vol. III) (1992) (Transfer of Environmentally Sound Technology, Cooperation and Capacity Building); id. at If 40.5 (Information for Decision-Making); The Realization of Economic, Social and Cultural Rights, Draft Resolution Submitted by Mr. Boutkevich, Mr. Chernichenko, Mr. Despouy, Mr. Eide, Mr. Maxim, Ms. Palley, Mr. Sachar, Ms. Warzazi and Mr. Yimer. Human Rights Dimensions of Population Transfer, Including the Implantation of Settlers and Settlements, Commission on Human Rights, Sub-Commission on the Prevention of Discrimination and the Protection of Minorities, 44th Sess., Agenda Item 8, at 2, U.N. Doc. E/ CN.4/Sub.2/1992/L.40 (1992); See generally Beyond the Numbers: A Reader on Potulation, Consumption and the Environment (Laurie Ann Miller ed., 1994).

10. See 2 The Gatt Uruguar Round: A Negotiating History (1986-1992) 2341-2425 (Terrence P. Stewart ed., 1993). See id. at 2367-68, citing Labor Movement and Trade in Services, GATT Doc. No. MTN.GNS/W/104 (18 Jun. 1990) at 2-3; Julian L. Simon, The EConomic Consequences of ImMicration 269 (1989); Canada-United States: Free Trade Agreement, 27 I.L.M. 281, 368 (1988); Preparations for the United Nations Conference on Environment and Development on the Basis of General Assembly Resolution 44/228 and Taking into Account other Relevant General Assembly Resolutions. Recent Actions 
rights organizations cannot seek effective protection of human rights without considering the impact of poverty, foreign investment, trade, and environmental degradation."

The intertwining of these problems has helped break down the distinction that the international community has sought to maintain between purely domestic and purely international problems. ${ }^{12}$ It is now almost impossible to find problems that do not have both domestic and international dimensions. In fact, problems have become transnationalized. ${ }^{13}$ A proper resolution to each problem, therefore, requires action on both the local and the global level.

Both the Bank and the IMF have responded to the intertwining of

of Intergovernmental and other Bodies of Relevance to the Preparatory Process. Environment and International Trade. Report of the Secretary-General of UNCTAD Submitted to the Secretary-General of the Conference Pursuant to General Assembly Resolution 45/210. Annex, International Environmental Agreements that Employ Trade Restrictions, Preparatory Committee for the United Nations Conference on Environment and Development, 3rd Sess., Provisional Agenda Item 2(B), U.N. Doc. A/CONF. 151/PC/ 48 (1991); Daniel C. Esty, Greening the GaTt: Trade, Environment and the Future (1994).

11. See, e.g., Diane F. Orentlicher \& Timothy A. Gelatt, Public Law, Private Actors: The Impact of Human Rights on Business Investors in China, 14 NW. J. INI'L L. \& Bus. 66 (1993); Philip Alston, International Trade as an Instrument of Positive Human Rights Policy, 4 Hum. Ris. Q. 155 (1982); Jonathan L. Mannina, The Human Rights Implications of Economic Development: A Case Study of the Hourarani Peoples of Ecuador, 5 Geo. INT'L ENVTL. L. Rev. 117 (1992); William Andrew Shutkin, International Human Rights Law and the Earth: The Protection of Indigenous Peoples and the Environment, $31 \mathrm{VA}$. J. INT't L. 479 (1991). See also the 1994 Draft Declaration of Principles of Human Richts and Environment, available from the International Program at the Sierra Club Legal Defense Fund. Its first principle declares the interdependence and indivisibility of human rights, an ecologically sound environment, sustainable development, and peace. $I d$.

12. For an overview see 9 AM. U. J. INI'L L. \& POL'Y 1-213 (1993) (containing papers presented at the Conference on Changing Notions of Sovereignty and the Role of Private Actors in International Law). The resulting internationalization of problems has also affected the classic way in which balance of power issues, both domestically and internationally, are perceived. In a reality based on a strict distinction between domestic and international issues, the executive branch of government assumed almost exclusive powers in the realm of international affairs. The erosion of the distinction between domestic and international issues has led to a situation in which exclusive executive power has assumed a different and less democratic character. In particular, because the legislative branch is the branch of government that most directly represents the sentiments of civil society and in which most of the battles for democratization of social life have been fought, this shift in power has created a substantial obstacle to the efforts by members of civil society to participate in the affairs of society that most directly affect them. These actors have been forced to adopt a broader definition of their scope of activity. Increasingly these actors are being forced to think and act globally as well as locally.

13. See generally, Claudio Grossman \& Daniel D. Bradlow, Are We Being Propelled Towards a People-Centered Transnational Legal Order?, 9 AM. U. J. INT'L L. \& PoL'y 1 (1993). 
problems by broadening the scope of their activities. ${ }^{14}$ The Bank has incorporated considerations of the environment, gender issues, governance, and public participation into its developmental mandate. ${ }^{15}$ The IMF has recognized issues such as the environment, social safety nets, and military expenditures as relevant to its monetary mandate. ${ }^{16}$

\section{B. Background on International Organizations}

The international organizations established after the Second World War were organized around the principle of sovereignty. This meant that only states were eligible for membership in these organizations. The member states alone had (and still have) a vote in the policymaking bodies of these organizations. Nonstate actors who wished to participate in these organizations were expected to present their claims through their state representatives. ${ }^{17}$

In accordance with the principles of sovereignty, the international organizations were granted limited ability to intervene in the "domestic affairs" of their member states. ${ }^{18}$

14. See, e.g., Latin American Countries' Progress Based on Fiscal Discipline, 24 IMF Surv. 1, 6 (1995) (interview with Sterie T. Beza, former Counsellor and Director of the Western Hemisphere Department of the IMF); Lewis T. Preston, The Bank's Goal is to help Members Reduce Poverty and Raise Living Standards 23 IMF Surv. 121, 310 (1994) (opening address to the Forty-Ninth Annual Meeting of the IMF and World Bank).

15. 1994 World Bank Annual Report, supra note 8, at 34-36, 46-47, 76; World Bank, Striking a Balance: The Environmental Challenge of Development (1989).

16. See generally, IMF Reviews Its Approach to Environmental Issues, 20 IMF SURv. 124 (1991); Seminar Explores Links Between Macro Policy and the Environment, 22 IMF SuRv. 177 (1993); Assessing the Reform Record in the Transition Economies, 24 IMF Surv. 2 (1995); Poverty Reduction and Structural Adjustment Discussed at IMF Seminar, 22 IMF Surv. 178 (1993); IMF Study Examines Cost of Military Spending, 20 IMF Surv. 193 (1991); Economic, Financial, and Political Factors Play a Role in Military Spending Decisions, 20 IMF Surv. 251 (1991).

17. The International Labour Organization (which predated World War II) is a partial exception to this rule. Nonstate actors may participate in the organization's work. However, they may not join the organization in their own right. See SCHERmers, supra note 3, at 121-22; Constitution of the International Labour Organization art. 7.

18. Article $2(7)$ of the United Nations Charter precludes the United Nations from intervening "in matters which are essentially within the domestic jurisdiction" of the state or from requiring member states "to submit such matters to settlement" under the Charter. The phrase "domestic jurisdiction" in the Charter underscored the international community's perception that there were a set of purely domestic issues and a set of purely international issues. The United Nations would only have the authority to address the purely international issues. See HENKIN, supra note 2, at 174. The IFIs were also required to respect their member states' sovereignty over their internal affairs. The World Bank was precluded form considering "political" issues in its lending decisions. See Agreement of the International Bank for Reconstruction and Development, arts. I, IV(10), $\mathrm{V}(5)(\mathrm{c})$, amended 17 Dec. 1965, T.I.A.S. No. 1507, 2 U.N.T.S. 134 [hereinafter IBRD Articles]; Aron Broches, Statement of the I.B.R.D. General Counsel to the Fourth 
The most important universal international organizations created after the Second World War were the United Nations, the IMF, and the IBRD. The United Nations was granted a broad mandate. The UN Security Council was granted the authority to deal with threats to the peace, breaches of the peace, and acts of aggression. ${ }^{19}$ The UN General Assembly was given the power to discuss any issue within the scope of the Charter, encompassing issues from human rights to international economic relations to peace and security. ${ }^{20}$

The IMF was mandated to regulate an international monetary order based on the member states' commitment to freely convertible currencies for current transactions and orderly exchange arrangements. ${ }^{21}$ The IBRD was established to fund the reconstruction of war-torn Europe and the development of the poorer countries of the world. Its mandate was to facilitate the investment of capital for production purposes and to encourage the development of the production resources of its member countries. ${ }^{22}$

The international community's support for international organizations and its willingness to place limits on state sovereignty was not unqualified. The effort to create the International Trade Organization (ITO), which would have regulated nonmonetary aspects of the international economy, resulted in failure. ${ }^{23}$ The only surviving remnant of this organization was the General Agreement on Tariffs and Trade (GATT). ${ }^{24}$ This intergovernmental agreement

Committee of the U.N. General Assembly on 28 Nov. 1966, 6 I.L.M. 150 (1967); SHiHAtA, supra note 8, at 62-79. The IMF, in its surveillance activities, is required to "respect the political and social policies of its member countries." Articles of Agreement of the International Monetary Fund, art. IV(3)(b), amended 1 Apr. 1978, 29 U.S.T. 2203, T.I.A.S. No. 8937 [hereinafter IMF Articles]. The legal form of the stand-by arrangement was designed, in part, to respect the sovereignty of its member states. See Joseph Gold, The Legal Character of the Fund's Stand-By Agreements and Why It Matters 35 IMF Pamphlet Series $5-7$ (1980).

19. See U.N. Charter ch. VII. Chapter VII of the United Nations Charter authorized the Security Council to take coercive action of a military, economic, or political nature against a member state that was deemed to be a threat to international peace. In practice, however, the veto power of the permanent members of the Security Council has prevented decisive action in most cases. This was particularly relevant during the Cold War. Alan M. James, Unit Veto Dominance in United Nations Peace-Keeping, in Poutics in the United Nations System 75 (Lawrence Finkelstein ed., 1988); Michael Howard, The Historical Development of the UN's Role in International Security, in United Nations, Divided Worid 63 (Adam Roberts \& Benedict Kingsbury eds., 1993).

20. U.N. Charter art. 10.

21. IMF Articles, supra note 18, art. 1(3).

22. IBRD Articles, supra note 18, art. I(1).

23. United States Department of State, Havana Charter for an International Trade Organization 3206 (1948).

24. See Kenneth W. Abbott, The General Agreement on Tariffs and Trade (GATT), in 1 BASIC Documents of International Economic Law 3 (Stephen Zamora \& Ronald A. Brand eds., 1990); Kenneth W. Dam, The GaTt: Law and International Economic Orcanization 10 (1970); John H. Jackson, The World Trading System 33-34 (1989). It should be noted that the 
established the framework for international trade in goods between the contracting parties. ${ }^{25}$

Even though they were organized around the principle of sovereignty, the establishment of the United Nations and the Bretton Woods institutions constituted a movement away from an international legal order based on absolute sovereignty. The charters of both the United Nations and the IMF create superstructures that operate above the level of the individual member states. Each member state agreed to surrender some aspect of its sovereignty in return for the benefits it expected to derive from membership in these organizations. For example, by joining the United Nations, member states agree to limit their ability to use force, submit to Security Council decisions relating to international peace and security, and accept the General Assembly's broad authority to publicly discuss issues of international concern, ${ }^{26}$ in anticipation of the political, economic, and security benefits they believe the United Nations can provide.

The actual benefits that states could derive from the United Nations have been constrained by problems beyond the control of that organization. For example, Cold War politics limited the Security Council's ability to take action in cases of threats to the peace. ${ }^{27}$ Serious differences of opinion between the richest countries and the developing countries have also hindered the United Nations' ability to act in the international economic arena. These deficiencies should not, however, be interpreted as meaning

recently concluded Uruguay Round of GATT negotiations addressed a number of topics that would have fallen within the ITO's jurisdiction. In addition, the states participating in the Uruguay Round agreed to establish a World Trade Organization that will perform a number of the functions that were envisaged for the ITO. See General Agreement on Tariffs and Trade - Multilateral Trade Negotiations (The Uruguay Round): Agreement Establishing the Multilateral Trade Organization [World Trade Organization], 33 I.L.M. 13 (1994).

25. GATT's application to trade in goods was not in fact comprehensive. Trade in agriculture and textiles were not regulated by GATT. The contracting parties agreed to exclude agricultural products from GATT negotiating rounds. Trade in textiles was regulated by the Multi-Fibre Agreement. See JACKSON, supra note 24, at 44-45, 181-83; Abbott, supra note 24 , at $233,239$.

26. U.N. Charter arts. 10, 11. The development of an international Bill of Rights, having as its point of departure the United Nations Charter, is a good example of the impact that the General Assembly can have on the behavior of the member states. See Surya Prakash Sinha, The Axiology of the International Bill of Human Rights, 1 PACE Y.B. INT'L L. 21 (1989) (discussing International Covenant on Civil and Political Rights, adopted 16 Dec. 1966, entered into force 23 Mar. 1976, G.A. Res. 2200 (XXI), 21 U.N. GAOR Supp. (No. 16), at 52, U.N. Doc A/6316 (1966); International Covenant on Economic, Social and Cultural Rights, adopted 16 Dec. 1966, entered into force 3 Jan. 1976, G.A. Res. 2200 (XXI), 21 U.N. GAOR Supp. (No. 16), at 49, U.N. Doc A/6361 (1966)).

27. The situation in the United Nations has changed since the end of the Cold War. See, e.g., Anthony Clark Arend, The United Nations and the New World Order, 81 Geo. L.J. 491 (1993). 
that the United Nations has always been ineffective. It has provided a forum for the discussion of, and the initiation of action on, many relevant issues facing the international community.

Moreover, in the cases of human rights, the environment, and decolonization, the United Nations has played an essential role in establishing entitlements, standards of conduct, and supervisory mechanisms that helped promote compliance with, and respect for, basic international norms. This was achieved through the organization's interpretation of the concept of "domestic jurisdiction." Early in its history the United Nations determined that the Charter provision prohibiting intervention in the domestic jurisdiction of its member states did not prevent it from debating and issuing recommendations on issues of interest to its members. The most prominent example of this creative use of UN powers is found in its treatment of apartheid. ${ }^{28}$

Similarly, by joining the IMF, member states agree to surrender some control over their exchange rate and monetary policy. In return, they expect to benefit from the existence of a set of international monetary rules that the IMF, through regular consultations with all member countries, could monitor and enforce. ${ }^{29}$ The perceived benefits include increased opportunities for economic growth and IMF financial support in case of balance of payments problems. Membership in the IMF also entitles states to join the World Bank, where poorer members can obtain financing for development projects. ${ }^{30}$ This financing, which entails the imposition of some nonfinancial

28. See generally, Özoemir A. Özcūr, Apartheid: The Uniteo Nations \& Peaceful Change in South Africa (1982).

29. In practice, enforcement of these rules would depend on how the member's deviation from the rules manifested itself. In cases where a member's monetary policies produced balance of payments problems requiring IMF financial assistance, the IMF would use its conditionality policies to enforce its rules. In all other cases the IMF would use peer pressure to try to encourage members to abide by the rules of the international monetary order. Joseph Gold, Strengthening the Soft International Law of Exchange Arrangements, in 2 Legal and Institutional Aspects of the International Monetary System: Selected Essays 515, 527-30 (Joseph Gold ed., 1984); Richard W. Edwards, JR., International Monetary Collaboration 638-42 (1985).

30. The World Bank classifies its member countries according to their GNP per capita. Those countries that have a GNP per capita of less than $\$ 4,865$ per annum (in 1994 dollars) are entitled to borrow from the IBRD. World Bank, The World Bank Operational Manual, at Operational Policy 3.10, Annex D (Sept. 1994). Citizens of all Bank member countries are eligible to bid on World Bank contracts. Thus, the richer Bank member countries benefit from the business opportunities created by the Bank's lending operations. In 1991, the United States General Accounting Office calculated that for each dollar the United States contributes to the Bank, it receives approximately $\$ 1.16$ in new business. Practices and Policies of International Financial Institutions, Hearing before the Subcommittee on International Development, Finance, Trade and Monetary Policy of the Committee on Banking, Finance and Urban Affairs, 102nd Cong., 2nd Sess., 57 (1992). 
conditions on borrowing countries, has also contributed to the erosion of absolute sovereignty. ${ }^{31}$

The member states' decision to grant the IFls limited supervision over state activities has proven to be remarkably dynamic. Over the past fifty years, the IFIs have steadily increased their involvement in, and their ability to exercise supervision over, their member countries' affairs. It should be noted that in the case of the IMF, which was designed to deal with the monetary affairs of all its member states, this development has been uneven. While the IMF is able to exercise substantial control over the affairs of its poorer member states, it has very little control over the behavior of its richer member states. ${ }^{32}$

Over time the IMF has also assumed some responsibility for dealing with the structural economic problems of developing countries. ${ }^{33}$ it has expanded the time horizons that it uses in its analyses, and over which it makes financial assistance available to its member states. As a result, the IMF has been able to incorporate some supply-side issues into the design of its adjustment programs. One consequence of this change is that the IMF pays more attention to the structural causes of balance of payments problems and is somewhat more sensitive to the social difficulties involved

31. See International Borrowinc: Necotiatinc and Structuring International Debt Transactions 127-45 (Daniel D. Bradlow ed., 3rd ed., 1994) (providing a sample IBRD loan agreement and a sample IDA credit agreement). The World Bank's articles stipulate that the member states must either be the guarantor or the borrower on all IBRD loan agreements. IBRD Articles, supra note 18, art. III (4)(i). It should be noted that in its early years, the IBRD was a conservative financial institution that did not play a significant international role. See Eoward S. Mason \& Robert E. Asher, The Worid Bank Since Bretton Woons 150 (1973) (remarking that initially the World Bank was not a major supplier of capital for development).

32. See Back It or Scrap it, Euromoney, Sept. 1990, at 30 (Joseph Gold notes that "[i]t is a serious embarrassment to the fund that its influence is only effectively exercised on the developing countries."); Jacques J. Polak, Strengthening the Role of the IMF in the International Monetary System, in Puluinc Tocether: The International Monetary Fund in a Multipolar World 45, 60 (Catherine Gwin \& Richard E. Feinberg eds., 1989); Robert S. Browne, Alternatives to the International Monetary Fund, in BeYONo BREtION WOOds: Alternatives to the Global Economic Order 57, 66 (John Cavanaugh et al. eds., 1994). See generally, Joseph Gold, Symmetry as a Legal Objective of the International Monetary System, 12 N.Y.U. J. INT'L L. \& POL. 423 (1980). See also Samuel I. Katz, Balance of Payments Adjustment, 1945 to 1986: The IMF Experience, AtLanil Econ. J., Dec. 1989, at 71, 73, available in LEXIS, Nexis Library, ASAP II File ("In practice, the IMF has never found any sanction to encourage cooperative action by surplus countries.").

33. See, e.g., Daniel D. Bradlow, The International Monetary Fund, The World Bank Group and Debt Management, in Legal Aspects of Debt Manacement (UNITAR 1993) (discussing the IMF's increasing responsibilities towards developing countries); Erb Emphasizes IMF Adaptability to Changing Global Conditions, 23 IMF SURV. 257 (1994) (interview with Richard Erb, Former Deputy Managing Director of the IMF); BaHRaM Nowzad, INTERNATIONAL Monetary Fund, Promotinc Development: The IMF's Contribution (1992); David M. Cheney, Promoting Economic Stability: The IMF's Compensatory and Contingency Financing Facility (International Monetary Fund 1994). 
in stabilizing and adjusting national economies. ${ }^{34}$ This, in turn, means that the IMF has been forced to address some of the developmental, as opposed to purely monetary, problems that confront its member countries. ${ }^{35}$

The functions performed by the Bank have also undergone substantial change. Confronted by the developmental problems of its borrower countries and by the failure of many Bank-funded projects to perform as expected, ${ }^{36}$ the Bank has shifted its lending focus from an almost exclusive concern with discrete development projects to a concern with the general policy environment within which the project must function. Accordingly, the Bank, in addition to its project lending operations, has begun to fund both general and sector-specific adjustment programs. The loans for these programs provide borrowers with quick disbursing general purpose support conditioned upon adoption of certain policy reforms. The conditions, which are contractually binding, relate to the adoption of certain institutional or legislative measures intended to "adjust" the structures within which economic activity occurs, or social and economic policy is made, so that these structures are more likely to produce economic growth. ${ }^{37}$

34. See The IMF and Stabilization: Developinc Country Experiences (Tony Killick ed., 1984) (noting that the IMF has been criticized for failure to pay adequate attention to the social impact of its policies); Giovanni Andrea Cornia et al., 1 adustment with a Human Face: Protecting the Vulnerable and Promotinc Growth (1987) (noting the need to incorporate concern for human welfare into IMF adjustment programs). Balakrishnan Rajagopal, Crossing the Rubicon: Synthesizing the Soft International Law of the IMF and Human Rights, 11 B.U. INT'L L.J. 81 (1993).

35. See, e.g. Jacques J. Polak, The World Bank and the IMF: The Future of their Coexistence, in Bretton Wood: Lookinc to the Future, Breiton Woods Commission C-149 (1994); Barry Eichengreen \& Peter B. Kenen, Managing the World Economy under the Bretton Woods System: An Overview, in Manacing the Worlo Economy: Fifty Years After Bretton Woods 46-47 (Peter B. Kenen ed., 1994).

36. The problems in the Bank's loan portfolio were discussed in an internal Bank study of the Bank's portfolio. See World Bank Portfolio Manacement Task Force, Effective Implementation: Key to Development Impact (Oct. 1992) (on file with authors).

37. See Paul Mosley et al., 1 Aid and Power: The Worlo Bank and Policy-based Lending 65-67 (1991) (discussing the World Bank's use of conditionality in its lending operations and policy dialogue between the World Bank and its member countries); SHIHATA, supra note 8 (describing the evolving role of the IBRD in a world which demands more of the World Bank than it has in the past); Joan M. Nelson, Introduction: The Politics of Economic Adjustment in Developing Nations, in Economic CRISIS AND Policy ChOICE 3-4 (Joan M. Nelson ed., 1990) (discussing stabilization of debt procedures as well as structural changes that stimulate economic growth). There is an intense debate over how successful these conditions have been in promoting sustainable development. Many countries that have undergone Bank and IMF-funded adjustment programs have experienced, in addition to macroeconomic stability and increased growth rates, widening income disparities, declining standards of human welfare, and deteriorating environments. See, e.g., Structural Adjustment and the Environment (David Reed ed., 1992); Beyond Bretton Woods, supra note 32; Dominic Hogc, The SAP in the Forest: The Environmental and Social Aspects of Structural Adjustment Procrammes in the Philippines, Ghana and Guyana (Friends of the Earth ed., 1993); Walden Bello et al., Dark Victory: The United States, Structural Adjustment and Global Poverty 32-65 (1994); Bonnie K. Campbell \& John Loxley, Structural Adjustment in Africa (1989). 
This shift in the focus of their operations has forced the Bank and the IMF to explicitly address the institutional constraints that influence the ability of the borrower to implement and sustain policy reforms. In so doing the Bank has been compelled to incorporate into its loan agreements conditions relating to those aspects of a country's governance that can influence its policymaking and implementing capacity. ${ }^{38}$ Similarly, the IMF has been forced to assist some of its members in "restructuring" their states. ${ }^{39}$

This means that, in fact, the Bank through its loan negotiations and ongoing dialogue with borrower states has become an active participant in the policymaking processes of its borrower countries. ${ }^{40}$ The IMF through its surveillance, technical assistance, and financing operations is also able to exert considerable influence over the policymaking process in those member states that actually need, or think they might need, access to IMF financing. ${ }^{41}$

The fact that these international organizations have been compelled by the evolution of their mandates to involve themselves in what had previously been considered purely internal matters has necessarily undermined the concept of absolute sovereignty. It has also forced these organizations to become more receptive to the calls of private actors for increased public participation in their affairs. ${ }^{42}$ These developments suggest

38. It should be noted that the Bank does seek to limit the issues it considers in examining a country's governance. However, the distinctions that it seeks to draw are arbitrary and ultimately unsustainable. For a description of the Bank's governance policies see SHIHATA, supra note 8, at 79-96; Worlo Bank, Governance and Development (1992); Worlo Bank, Governance: The World Bank's Experience (1994).

39. Michel Camdessus, Managing Director of the IMF, recently stated that the IMF is involved in efforts to restructure the state in Central and Eastern Europe, Latin America, Africa, and Asia. Camdessus Discusses Progress in Transition Economies in Central and Eastern Europe, 24 IMF Surv. 21, 21-24 (1995).

40. The Bank's ability to play this role is enhanced by its influence over the borrower country's other potential sources of funds. See Robert Cassen \& Associates, Does Aio Work? 69-117 (1986); Mosley ET Al., supra note 37, at 51. For further discussion of this issue, see infra SIV A. See also Jonathan Cahn, Challenging the New Imperial Authority: The World Bank and the Democratization of Development, 6 HaRv. Hum. RTS. J. 159, 171-80 (1993) (providing a description of the objective, the scope, and the implementation of the concept of policy-based lending); Sigrun I. Skogly, Structural Adjustment and Development: Human Rights-An Agenda for Change, 15 Hum. Ris. Q. 751 (1993) (commenting on the interplay between human rights and development).

41. See, e.g., IMF Assessment Project, IMF Conditionaliry: 1980-1991 (1992); Rajagopal, supra note 34 , at 103 .

42. The most significant example of this is the World Bank's adoption of a new information disclosure policy and establishment of an independent Inspection Panel in 1993. The panel investigates complaints from directly affected private parties regarding the World Bank's failure to follow its own operating rules and procedures. See IBRD Resolution on the Inspection Panel No. 93-10 and IDA 93-6; IBRD Resolution on Disclosures of Operational Information, in Worlo Bank Operation Manual-Bank Procedures, BP17.50 (World Bank ed., 1993). See generally, Daniel D. Bradlow, International Organizations and Private Complaints: The Case of the World Bank Inspection Panel, 34 VA. J. INT'L L. 
that the IFIs need to reformulate both their operating procedures and responsibilities, and to reconsider their relations with other international organizations to reflect their changed functions. Some proposals in this regard are discussed in the last section of this paper.

\section{The New International Actors}

The complexities created by intertwined problems are compounded by a dramatic increase in the number of actors on the international stage. Business organizations; national liberation movements; consumer, environmental, human rights and other NGOs; political parties; individuals; and trade unions have all become significant actors on the international stage. These private actors have begun to develop transnational affiliations and the capacity to operate internationally to effectively pursue their interests.

The most significant example of this phenomenon is the rise in prominence of the transnational corporation (TNC). ${ }^{43}$ While TNCs have existed for centuries, their ability to plan and operate on a global basis grew dramatically as the post-Second World War era unfolded. Stimulated by new investment opportunities and technological developments, TNCs have developed the ability to produce their goods and services in multiple, interconnected locations. This has encouraged global production and distribution patterns and transnational strategic planning.

The fact that TNCs have multiple production facilities means that they now have an increased ability to evade state power and to undermine the efficacy of national regulatory schemes by moving their operations around the world. This growth in corporate power poses a problem for the international community. First, it means that, whatever the legal status of the state may be, the sovereign has lost power to TNCs in terms of its ability to control the human, natural, financial, and technological resources located in its territories.$^{44}$ It also means that private actors-trade unions, consumer groups, environmental organizations-that traditionally interact with TNCs

553 (1994); Ibrahim F.I. Shihata, The Worlo Bank Inspection Panel (1994). See also Daniel D. Bradlow \& Sabine Schlemer-Schulte, The World Bank's Inspection Panel: A Constructive Step in the Transformation of the International Legal Order, 54 ZAÖRV (HeIdel BerG ). INT'L LAw) 392 (1994).

43. There is extensive literature on TNCs. See, e.g., Richard J. Barnet \& John Cavanach, Giobal Dreams (1994); Raymond Vernon, Sovereicnty at Bay (1971); Richard J. Barnet \& Ronald E. Muller, Global Reach: The Power of the Multinational Corporations (1974); Jean J. ServanSchreiber, The American Challence (1968); Robert B. Reich, Who is Us?, Harv. Bus. Rev., Jan,-Feb. 1990, at 53; Robert B. Reich, The Work of Nations (1991); World Investment RePORt (1994), UNCTAD (Sales Nr. E.94.II.A.14).

44. The top 500 TNCs account for 30 percent of the world's gross product, 70 percent of world trade, and 80 percent of world investment. Norman Myers, Debate: Gross Reality of Clobal Statistics, The Guardian, 2 May 1994, at 9. The power of private corporations is 
on a country-by-country basis are being forced to transnationalize so that they can interact with TNCs in a meaningful way.

The growing influence of TNCs and other nonstate actors also affects international organizations. Today international organizations, like the state, cannot effectively perform their functions without the support and participation of these nonstate actors. ${ }^{45}$ Consequently, these organizations cannot expect to effectively implement their mandates simply by reaching agreements with their member states.

Both the Bank and the IMF have begun to recognize the importance of nonstate actors. In recent years, the Bank has recognized the importance of borrower participation ${ }^{46}$ and a sense of beneficiary ownership to the success

also evident from a comparison of their financial resources relative to the gross domestic product of five of the richest countries. See Rank by Sales Volume, DUN's Business Rankincs, sec. VII (Dun \& Bradstreet eds., 1993) (citing the 1992 sales volume for General Motors $(\$ 123,056,000,000)$, Exxon $(\$ 115,068,000,000)$, Ford Motors $(\$ 88,286,300,000)$, IBM $(\$ 64,523,000,000)$, and AT\&T $(\$ 63,089,000,000))$; The Corporate Finance Bluebook $\$$ 8 (National Register Publishing ed., 1993) (providing figures on the assets of various companies including: General Motors $(\$ 184,325,500,000)$, Exxon $(\$ 87,560,000,000)$, Ford $(\$ 174,429,400,000)$, IBM $(\$ 92,473,000,000)$, and AT\&T $(\$ 53,355,000,000))$; ANnual Report to Shareholders: Fortune 500 (Washington Disclosure, Inc., ed., 1993) (expanding upon these basic figures); WORLD TABLES 257, 269, 349, 625, 629 (Johns Hopkins Univ. Press ed., 1993) (providing figures on the 1990 gross domestic product of the following countries: France (Franc 6,484, 109,000,000, equalling $\$ 1,162,026,000,000$ ); Germany (DM 2,404,540,000,000, equalling \$1,448,518,000,000); Japan (Yen $425,735,000,000$, equalling $\$ 2,799,100,000)$; United Kingdom ( $£ 549,181,000,000$, equalling $\$ 315,621,000,000)$; United States $(\$ 392,200,000,000)$. All conversions were made by the author based upon New York Stock Exchange trading rates of 30 June 1990).

45. The World Bank has made significant efforts to improve its interactions with nongovernmental actors. See, e.g., Nongovernmental Organizations and the Worlo Bank (Samuel Paul \& Arturo Israel eds., 1991); Ibrahim F.I. Shihata, The World Bank and Non-Governmental Organizations, 25 Cornell Int'l. L.J. 623 (1992); Worlo Bank Operational Manual, Operational Directive 14.70: Involving Non-governmental Organizations in Bank-Supported Activities (Aug. 1989); Bruno J. Mauprivez, Local People Must be Involved in Developmental Decisions, 20 IMF Surv. 53 (1991).

The IMF's relations with nongovernmental actors are less developed. See Richard Gerster, Accountability of Executive Directors in the Bretton Woods Institutions, $27 \mathrm{~J}$. WORLD TRADE 87 (1993), for the view that "li]n Fund operations, NGOs do not play any role at all." Id. at 89 . It should be noted that the charters of both organizations require the IFIs to deal with their member states through the Ministry of Finance, the Central Bank, or some other agency designated by the state for this purpose. See IBRD Articles, supra note 18, art. III(2); IMF Articles, supra note 18, art. V(1). This requirement may impair the IFIs' ability to interact with nongovernmental actors, but it should not be an insurmountable problem.

46. World Bank, Guidelines for Incorporating Social Assessment and Participation into Bank Projects (Draft Memorandum) (14 Feb. 1994); Participatory Development and the World Bank: Potential Directions for Chance (Bhuvan Bhatnegar \& Aubrey $C$. Williams eds., 1992) (Discussion Paper No. 183); Willaam J. NaGle \& Sanjor Ghose, Community Pariacipation in Worlo Bank Supported Proiects (1990) (Discussion Paper No. 8); Celia R. Taylor, The Right of Participation in Development Projects, 13 Dick. J. INT'L L. 69 (1994). 
of development projects. ${ }^{47}$ It has also created an NGO-World Bank Committee in which representatives of NGOs and World Bank officials regularly meet to discuss matters of mutual concern..$^{48}$ Partially due to the influence of NGOs, the Bank has created a Public Information Center and a more open public information policy. ${ }^{49}$ In addition, the Bank has established an independent inspection panel with the power to investigate allegations that private actors have been harmed, or will be harmed, by the Bank's failure to follow its own operating rules and procedures..$^{50}$ Finally, a senior Bank official recently proposed that the Bank restructure its project cycle to more effectively incorporate private actors into the design of all Bankfunded operations. ${ }^{51}$

The IMF engages in much more limited interactions with private actors. Nevertheless, it has expanded its informal contacts so that IMF officials, including Executive Directors, hold discussions on a wide range of issues with private actors such as TNCs and NGOs involved in environmental, labor, and developmental issues. ${ }^{52}$ Partially in response to the concerns of these private actors, the IMF has begun to more systematically incorporate environmental and social factors into its work. ${ }^{53}$ In addition, it has begun to review its policy towards the public release of reports based on Article IV consultations between the IMF and their member states. ${ }^{54}$ Also, the IMF has begun to consider the possibility of a more liberal information disclosure policy. ${ }^{55}$

The United Nations also has responded to the challenge raised by nonstate actors. For example, in the decolonization process, it recognized

47. See World Bank, Getting Results: The Worlo Bank's Acenda for Improving Development Effectiveness 11 (1993).

48. Marcos Arruda, NGOs and the World Bank: Possibilities and Limits of Cooperation (1992); Shihata, supra note 45; Paul \& IsRael, supra note 45.

49. See Worlo Bank, The World Bank Policy on Disclosure of Information (1994); The World Bank Operational Manual, Bank Procedure 17.50: Disclosure of Operational Information (Sept. 1993).

50. See, supra note 42.

51. See Robert Picciotti \& Rachel Weaving, A New Project Cycle for the World Bank? 31 Fin. \& Dev. 42 (1994).

52. Richard Gerster, A New Framework of Accountability for the IMF, in Berond BRetron Woods, supra note 32 , at $94,99$.

53. See S. Fisher, Statement to the Meeting of International Parliamentarians, hosted by the Banking Committee of the US House of Representatives and its Subcommittee on International Development, 21 Nov. 1994. Mr. Fisher, Deputy Managing Director of the IMF, states that the IMF seeks to ensure "appropriate emphasis on social sectors within the overall macroeconomic strategy" in advice, technical assistance and financial support to its member states, that the IMF has begun to expand its work in the environmental area to "improve understanding of the interactions between macroeconomic policies and the environment," and has begun to discuss labor policies with its member countries. Id. at 6 .

54. Id, at 3-4.

55. Id. 
the existence of national liberation movements. ${ }^{56}$ In the human rights field, to differing extents, individuals claiming that they are victims of violations of internationally recognized human rights have been granted rights of action at the international level. Institutionally, the United Nations has created bodies of independent experts who serve in their individual capacities, without receiving instructions from state actors. ${ }^{57}$

\section{THE CHALLENGE FOR THE IFIS}

The intertwining of problems and the increased influence of nonstate actors in international affairs poses two challenges to international organizations, in general, and to limited mandate organizations, like the IFIs, in particular. The first challenge is to adjust operating procedures to accommodate the IFIs' role as a player in the policymaking processes of many of their member countries. The second challenge is to ensure that the IFIs have a sufficiently detailed understanding of their members' monetary and development needs so that IFIs can fully respond to all the problems falling within their specialized areas of responsibility, without acting ultra vires by assuming sole responsibility for matters outside the scope of their limited mandates.

\section{A. The IFIs as Policymakers}

The World Bank is engaged in a broad ranging policy dialogue with its borrower countries. Because the Bank now makes policy-based loans as well as project loans, these dialogues cover the economic, social, and environmental aspects of the member state's proposed development plans, the role of the state in its development process, and the state's ability to implement its plans. Through this dialogue, and its lending decisions, the Bank is able to influence the member state's policies and priorities. This influence is projected through the terms and conditions the Bank incorporates into its loan agreements. In effect, the Bank plays a role in both the formulation and the implementation of policy in its borrower countries. ${ }^{58}$

56. See, e.g., Jamal R. Nassar, The Palestine liberation Organization 27-28, 42 (1991); G.A. Res. No. 3237, U.N. GAOR, 29th Sess., Supp No. 31, at 4, U.N. Doc. A/9631 (1974) (inviting the PLO "to participate in the sessions and the work of the General Assembly" and "of all international conferences concerned under the auspices of the General Assembly in the capacity of observer").

57. See, e.g., Ian Sinclair, The International Law Commission 13-21 (1987).

58. See supra notes 37,40 . 
The Bank's role creates both the potential, and the need, for it to engage in a dialogue with nongovernmental actors affected by its policy, as well as those actors who have the ability to influence that policy's success.

The IMF conducts broad ranging surveillance missions in its member countries. During the course of these missions, the IMF and the member state discuss all aspects of the member's policies that are relevant to the IMF's mandate..$^{59}$ Given that monetary and exchange rate policies affect and are affected by all aspects of an economy, these discussions might include, in addition to macroeconomic issues, policies regarding trade, social welfare, fiscal health, banking, the environment, labor, health care, and military expenditures. The role of the state and markets in the economic policies of the member states might also be considered. ${ }^{60}$ These discussions influence the suggestions the IMF makes to its member countries, the content of the issues it seeks to incorporate into Policy Framework Papers and standby arrangements, and the conditions it attaches to its financial arrangements with member states.

It should be noted that both the IMF and the Bank are careful to ensure that the forms of their interactions with their member states do not undermine the sovereignty of those states. Consequently, regardless of how the policies are developed, the member state, and not the IFIs, bears legal responsibility for the design and implementation of these policies. The formal legal situation, however, should not be confused with the functional reality, which is that the IFIs do play a role in the policymaking processes of some of their members. Legal formalism should not allow the IFIs to escape responsibility for the consequences of their actions in these processes. ${ }^{61}$

It is important to recognize that the IFIs are only capable of exercising

59. See Decision No. 6026-(79/13), 22 Jan. 1979, amended by Decision No. 10273-(93/15), 29 Jan. 1993; Decision No. 10364-(93/67), 10 May 1993, in 19 Selected Decisions and Selected Documents of the International Monetary Fund 9-14 (30 June 1994).

60. Under the original IMF Articles of Agreement, all member states were bound to maintain relatively fixed exchange rates. This par value system imposed some limits on the IMF's discussions with its member countries. The IMF could limit its concerns to those issues which directly affected the member state's ability to maintain its currency's par value. Under the present system of free exchange rates, all factors can affect a country's ability to maintain a stable balance of payments position. Thus the IMF needs information on all aspects of a member state's economy. See, e.g., IMF Study Examines Costs of Military Spending, 20 IMF Surv. 193, 205 (1991); Joseph Gold, Natural Disasters and Other Emergencies Beyond Control: Assistance by the IMF, 24 INT'L L. 621, 621 (1990). But see, e.g., Joseph Gold, Political Considerations are Prohibited by IMF When Fund Considers Requests for Use of Resources, 12 IMF Surv. 146 (1983).

61. See infra Part IV. See also Thomas Hutchins, Using the International Court of Justice to Check Human Rights Abuses in the World Bank Projects, 23 Coum. Hum. Ris. L. Rev. 487 (1991); Victoria E. Marmorstein, World Bank Power to Consider Human Rights Factors in Loan Decisions, 13 J. INT'L L. \& ECON. 113 (1978); Skogly, supra note 40. 
power and influence over those member countries that actually make use of their financing services. This means that their power is only exercised over the poorer and weaker countries of the international community.

The IFIs' policymaking role poses two challenges. First, how can the IFIs perform a policymaking function while supporting the capacity of affected parties to participate in their states' decisionmaking processes? Second, how can these affected parties hold the IFIs accountable for the consequences of their actions?

\section{IFls and Participation}

All international actors who play a role in the making and implementation of a state's development policy assume certain international legal responsibilities. These responsibilities are determined partly by the international treaties that the state has signed and partly by general principles of international law that bind all international legal actors.

In this regard, it should be noted that international organizations, such as the IFIs, are both subjects of international law and bound by its norms. ${ }^{62}$ For this reason, the IFIs cannot provide funds to countries practicing genocide, intending to use the funds to finance a war, or promote racial discrimination. Furthermore, international organizations should not promote policies or provide funding in a manner that would undermine the member states' ability to fulfill their own freely assumed international legal commitments. ${ }^{63}$ This is particularly pertinent in the case of international environmental and human rights agreements.

The principles of international human rights law suggest that the IFIs have an obligation to ensure that their operating procedures are open to participation by those nonstate actors directly affected by the IFIs' various operations. The precise level of participation may vary from case to case, depending on both the character of the specific IFI operation and the participatory nature of the borrower state's own decisionmaking processes. However, to ensure that they satisfy their own international legal obligations, the IFIs need to develop formal and transparent mechanisms that will ensure at least a minimum level of participation in all their operations. These mechanisms can include whatever fora and techniques are deemed

62. Reparations for Injuries, supra note 3; see also, lan Browntie, Principles of Public InTERNATIONAL LAW 679-707 (4th ed., 1990).

63. In essence this means that the precise international legal responsibilities of the IFIs will vary from country to country, depending on the treaties that each state has signed. However, in general, it is safe to assume that the IFIs should perform their functions in a way which supports the fundamental rights of individuals and peoples. Any additional obligations would depend on the treaties signed by individual member states. 
appropriate for gathering information from all the stakeholders in each of the IFIs' operations. ${ }^{64}$

In establishing these mechanisms, the IFIs should ensure participation by actors who are precluded by the borrower state from participation in its policymaking process. The IFIs should also provide an opportunity for participation to those who do not take advantage of existing processes because they fear retribution from more powerful actors who oppose their participation. For example, the IFIs could establish a mechanism that allows affected people to confidentially submit information outside the member state. Alternatively, they could allow representatives of those potentially or already affected by IFIs' operations to formally present information on their behalf.

\section{IFIs as Policymakers}

There are two dimensions to the IFIs' responsibilities at the policymaking level. First is the creation of the substantive economic and social policies of the IFIs. Because these policies help determine both the types of activities the IFIs fund and the design and implementation of these activities, nonstate stakeholders in the IFIs' operations have an obvious interest in participating in the IFIs' substantive policymaking process. ${ }^{65}$ The IFIs can meet these stakeholders' interest by building a number of points at which private actors would have a formal right to participate into the policymaking process. These could include the extension of formal and timely invitations to all stakeholders to submit information and proposals on particular issues currently under policy review. Once the IFIs have had an opportunity to consider these submissions, they could prepare a draft version of the particular policy, which could then be submitted to a public comment period. The finalized policy statement could then be published together with a discussion of the comments that the IFIs received.

An additional method for including the views of nonstate actors in the IFIs' policymaking process would be to introduce nonstate actors directly into the IFIs' decisionmaking and supervisory processes. Each institution, for instance, could establish a body or bodies of independent experts appointed

64. An interesting example in this regard is the International Labour Organization, where employers, workers, and governments participate in some policymaking activities. See supra note 16.

65. At present, the IFIs informally consult interested parties on their proposed policies. However, this process is ad hoc and is not open to all interested parties. A more formal process would ensure that all interested parties have a fair and meaningful opportunity to participate in the IFIs policymaking. 
in their individual capacities from the ranks of the member states. These bodies could have the power to make authoritative recommendations.

An example of such a body would be an expanded and strengthened version of the IBRD's presently defunct Advisory Council. Pursuant to Article $V(6)(a)$ of its Articles of Agreement, the IBRD is empowered to establish an Advisory Council that consists of at least seven persons selected by the Board of Governors, who shall "include representatives of banking, commercial, industrial, labor and agricultural interests." This formulation allows the IBRD to expand the Advisory Council to include representatives of development, environment, women's rights, and human rights NGOs. The Articles stipulate that in those fields where specialized international organizations exist, the Bank shall select Council representatives who are expert in these areas in consultation with the relevant specialized agency. The Council's mandate is to "advise the Bank on matters of general policy." While the Council only has advisory powers, by publicizing its findings and recommendations, and by allowing interested parties to submit information to it, the Council could serve a useful function in ensuring that IBRD policies incorporate the views of nonBank actors. It could also help publicize and stimulate discussions on the IBRD's existing and proposed policies.

Article $\mathrm{V}(6)(\mathrm{a})$ also states that the Council shall meet annually "and on such other occasions as the Bank may request." Nothing prevents the IBRD from requesting that the Council hold regular meetings more frequently than once a year. The Council could also decide to establish specialized subcommittees, that could hold regular and frequent meetings in their area of concern.

The second dimension to the IFIs' responsibilities at the policy level concerns the process through which the IFIs formulate their internal operating rules and procedures. These rules influence all aspects of the IFIs' operations, including the degree to which the IFIs' staffs are held accountable for their actions by both the IFIs' management and parties affected by their actions. Unfortunately, these rules are developed, implemented, and interpreted by the IFIs without a formal mechanism for participation by outsiders. The lack of transparency in this process is counter to the principles of good governance advocated by the IFIs. Therefore, the process should be opened up to greater public participation by adopting the same notice and comment procedure that was described for incorporating public participation into substantive policymaking in the Bank.

It should be noted that the IFIs' policymaking role is complicated by the restrictions that their charters impose on them and by the way in which these restrictions have been interpreted. The constraints are more restrictive in the case of the Bank than the IMF.

The IBRD's Articles of Agreement preclude it from intervening in the "political affairs" of its member countries or from being influenced by the 
"political character" of its member states. ${ }^{66}$ In other words, the Bank is required to only take "economic considerations" into account in its decisionmaking. In fact, the Bank, through its history, has interpreted and reinterpreted "economic considerations." With each new interpretation of its developmental mandate, the Bank has expanded its interpretation of this term and, concurrently, narrowed its interpretation of the scope of the political prohibition established by Article IV $(10) .{ }^{67}$ As a result, the Bank, which used to lend primarily to discrete infrastructure projects, is now able to fund such projects as the reform of a country's judiciary or public sector management. Recently, the Bank appears to have broadened the range of human rights issues that it views as falling within its mandate. ${ }^{68}$

While these developments are to be welcomed, they are not sufficient. The Bank usually uses this creative interpretation in an ad hoc manner. Thus, the Bank contends that it has the authority to address human rights issues it wishes to address, such as female genital mutilation, while arguing that it does not have the authority to address other important human rights issues, such as the prevention of torture or the suppression of political dissent, because the latter are purely "political" issues that do not have a "direct" economic effect. ${ }^{69}$ The arbitrary nature of this situation becomes clear when one takes into account the connection between freedom of the

66. Art. IV(10) states:

The Bank and its officers shall not interfere in the political affairs of any member; nor shall they be influenced in their decision by the political character of the member or members concerned. Only economic considerations shall be relevant to their decision and these considerations shall be weighed impartially to achieve the purposes stated in Article I.

See IBRD Articles, supra note 18. See also id. at arts. III(5)(b) (stating that the purposes for granting the loan should be disassociated from political or other "non-economic" factors), $V(5)(c)$ (stating that the members of the Bank shall respect the international character of the duties of the staff and "shall refrain from all attempts to influence them in the discharge of their duties"). The Articles of Agreement of the International Development Association contain the same resolution. See id. at arts. V(6) (political activity prohibited), $\mathrm{VI}(5)(\mathrm{c})$ (describing the international character of IDA staff), $\mathrm{V}(1)(\mathrm{g})$ ("non-economic" factors cannot be considered in its lending decisions). See also SHIHATA, supra note 8 , at 83 .

67. For a more detailed discussion of the Bank's interpretation of this provision, see Ibrahim F.I. Shihata, Human Rights, Development and International Financial Institutions, 8 Am. U. J. INT'L L. \& Pol'r 27, 30 (1992); Yozo Yokota, Non-Political Character of the World Bank, 20 Japanese Ann. Int'L L. 39 (1976); David Gilles, Human Righis, Democracr and "Good Governance": Stretching the World Bank's Policy Frontiers (International Centre for Human Rights \& Democratic Development, Montreal 1994). See also Marmorstein, supra note 61 .

68. For example, the Bank won a pledge from Burkina Faso to take steps to combat female genital mutilations. See George Graham, Pledge Over Female Mutilation, Financial Times, 22 Apr. 1994, at 6.

69. The more powerful member states have always recognized that the Bank's work is inherently political and, on occasion, have been willing to use the Bank to help resolve problems with states with whom they had political differences. Good examples are the cases of Chile, Nicaragua, and China. See Batram S. Brown, The United States and the Polticization of the World Bank: Issues of International Law and Policy (1992). 
press and hunger, ${ }^{70}$ and between freedoms of speech and association, transparent and accountable governance, and economic development. ${ }^{71}$

This suggests that the Bank needs to develop a more consistent interpretation of the political prohibition in its charter, and a better understanding of the relationship between human rights, governance, and development. In addition, now that it has accepted the importance of participation to sustainable development, it needs to acknowledge that it has an obligation to protect those who suffer human rights violations as a result of their participation in the Bank's operations.

The IMF's Articles of Agreement require it to "respect the political and social policies" of its member states. ${ }^{72}$ This has been interpreted as requiring the IMF to refrain from interfering in domestic political affairs. ${ }^{73}$ Nevertheless, the IMF has expanded the range of issues it considers in its consultations with member states, and in the policies it attaches to its financing operations. ${ }^{74}$ At least in public comments, the IMF has not recognized a need to differentiate between issues falling within the scope of its mandate, in the sense that they are relevant to the performance of its monetary function, and those that are outside of the mandate, in the sense that incorporation of these issues into its dealings with member states would constitute "disrespect" for the political and social policies of those states. ${ }^{75}$

\section{B. IFI Accountability}

Because the IFIs, through their policymaking functions, now directly affect the lives of many private persons, they need to provide these persons with

70. Economist Amartya Sen has concluded: "There has never been a famine in any country that's been a democracy with a relatively free press. I know of no exception. It applies to very poor countries with democratic systems as well as to rich ones." Sylvia Nasar, $1 t^{\prime} s$ Never Fair to Just Blame the Weather, N.Y. Times, 17 Jan. 1993, \$ 4, at 1, 5. See also JeAN Dreze \& Amartya Sen, Hunger and Public Action 263-64 (1989); Amartya Sen, Resources, Values and Development 500-03 (1984); N. Ram, An Independent Press and Anti-Hunger Strategies: The Indian Experience, in The Political Economy of Huncer 146 (Jean Dreze \& Amartya Sen eds., 1990).

71. See supra note 46.

72. Art. IV(3)(b) of the IMF Articles directs the Fund to adopt "specific principles for the guidance of all members with respect to ... [their exchange rate policies] . . . these principles shall respect the domestic social and political policies of members, and in applying these principles the Fund shall pay due regard to the circumstances of members." IMF Articles, supra note 18. The IMF Articles also request member states to respect the international character of the IMF officials' work. See id. at art. xii(4)(c); IBRD Articles, supra note 18 , at art. $\mathrm{V}(5)(\mathrm{C})$.

73. See Joseph Gold, The Rule of Law in the International Monetary Fund 59-60 (International Monetary Fund Pamphlet Series No. 32, 1980); Gold, supra note 60, at 148.

74. See supra notes $31-33,37$ and accompanying text.

75. See Goto, supra note 73, at 59-60; Gold, supra note 60. The articles also request member states to respect the international character of the IMF. IMF Articles, supra note 18 , at art. XII(4)(i). 
a means to hold the IFIs accountable for their role in the design and implementation of specific operations. The recently established World Bank Inspection Panel provides a useful model for the IMF and the other multilateral development banks. ${ }^{76}$

This Panel will review and investigate complaints from any group of two or more people who allege that they have been harmed by the failure of the Bank to comply with its own operational rules and policies. The Panel's powers are advisory and investigatory. In all cases final decisionmaking power resides with the Bank's Executive Directors. However, the Bank is required to make all the complaints, all the findings and recommendations of the Panel, and all the Executive Directors' decisions publicly available. In addition, the Panel is required to publish an annual report. Thus, even though the Panel has limited powers and limited jurisdiction, it has the ability to influence the Bank's operations and the content of its operational rules and policies. Over time, it also might begin to affect the process the Bank utilizes in formulating these operating rules and procedures. ${ }^{77}$

\section{Relations with Other Institutions}

\section{Relations Between the IMF and the Bank}

The expanding operations of the Bank and the IMF have resulted in increased possibilities for duplication in their operations and the issuance of conflicting advice. This has led to more systematic coordination between the two organizations. The most obvious manifestation of this development is the Policy Framework Paper. ${ }^{78}$ This paper is prepared, in conjunction with

76. All the regional development banks except the European Bank for Reconstruction and Development have established, or have publicly stated their intent to establish, Inspection Panels. IDB Independent Investigation Mechanism (on file with authors); African Development Bank Draft Statement on Proposed ADB Inspection Panel (3 Oct. 1994) (on file with authors); IDB to Have Independent Investigative Pane/s, INTER-AMERICAN Development Bank Press Release, 10 Aug. 1994; Asian Aid Bank Comes Under Fire at Annual Meeting, Reuters Worto Service, 2 May 1994, available in LEXIS, CURNWS File (President Matsuo Sato promises NGOs to "set up an inspection panel ... which will review the procedures for projects funded by the bank"). See also Statement of Susan B. Levine, Deputy Assistant Secretary of the Treasury for International Development, Debt and Environment Policy Before the Subcommittee on International Development, Finance, Trade and Monetary Policy of the House Committee on Banking, Finance and Urban Affairs, 19 May 1994 (Reporting that donors have "agreed that an information policy and an inspection function, analogous to those negotiated at the World Bank, should be established to strengthen the transparency and accountability of the [African Development] Fund").

77. See Bradlow, supra note 42.

78. See The Worlo Bank Operational Manual, Operational Directive 2.20: Policy Framework Papers (Oct. 1989). See also Richard E. Feinberg, The Changing Relationship between the 
the IMF and the Bank, by those member countries eligible for funding from the IMF's Enhanced Structural Adjustment Facility. ${ }^{79}$ The paper is adopted only after both organizations find the document acceptable. The policies spelled out in the paper are the basis on which the IMF provides funds from the Enhanced Structural Adjustment Facility to the member country. It might also provide the basis on which the International Development Association (IDA) will lend money to the country for adjustment purposes.

The establishment of the Policy Framework Paper process has helped borrower countries by reducing the risk that they will receive conflicting advice from the IFIs, as well as by streamlining the negotiation process with the Bank and the IMF. One potential problem with this process, given the fact that other funding sources often take their lead from the IFIs, is that it may effectively reduce a country's policymaking options.$^{80}$ Because coordination between the IFIs is essential, the solution to this problem should be found in a more participatory negotiation process.

\section{Relations With Other International Organizations}

The progressive broadening of the operations of the IFIs has resulted in their work encroaching into the spheres of expertise of other international organizations. This necessitates a rethinking of the relations between the IFIs and other international organizations, particularly the other specialized agencies in the UN system and the regional systems.

The Relationship Agreements between the IFIs and the United Nations, while acknowledging that the IFIs are UN specialized agencies, only requires that the IFIs "consider" the decisions and recommendations of the United Nations. ${ }^{81}$ The IFIs have interpreted these agreements as not

World Bank and the International Monetary Fund, 42 INT'L OrG. 545 (1988); Hiroyaki Hino, IMF-World Bank Collaboration, 23 FIN. \& Dev. 10 (1986). For an historical perspective on Bank-IMF relations see Joseph Gold, The Relationship Between the International Monetary Fund and the World Bank, 15 CReICHTON L. Rev. 499 (1982).

79. This facility has been renewed and expanded. IMF's Executive Board Approves Renewed and Enlarged ESAF, 23 IMF Surv. 1 (1994); New ESAF Begins Operations, 23 IMF Surv. 65 (1994).

80. The Policy Framework Paper may be distributed to the country's other official donors, and, with its consent, to nongovernmental sources. See Operational Directive 2.20, supra note 78, ๆ 31 .

81. See Agreement Between the United Nations and the International Monetary Fund, art. IV(2), 16 U.N.T.S. 328, 332 (1948) [hereinafter IMF Relationship Agreement]; Agreement Between the United Nations and the World Bank, art. IV(2), 16 U.N.T.S. 346, 348 (1948) [hereinafter Bank Relationship Agreement]. In comparison, the agreements between the United Nations and the ILO, and between the United Nations and the WHO, require that the specialized agencies arrange for submission of UN recommendations to their governing bodies "as soon as possible," to consult with the United Nations on these recommendations, and to report to the United Nations on the actions it has taken to give effect to these recommendations or on the results of their consideration of the 
requiring them to comply with UN decisions or recommendations. ${ }^{82}$ Although this interpretation is not universally accepted, ${ }^{83}$ the IFIs continue to contend that they have the authority to decide whether to comply.

The IFIs also are required to give "due consideration" to UN requests for the introduction of agenda items at the meeting of the IFIs' Board of Governors. ${ }^{84}$ In addition, the IFIs' component organizations are required, "to the fullest extent practicable," to arrange to exchange information, special reports, and publications. ${ }^{85}$ This requirement is subject to the need to "safeguard" confidential information. Accordingly, each organization is free to decide what information to withhold from the others. ${ }^{86}$

Over the years, the IFIs have jealously guarded the independence that the Relationship Agreements give them. They have interpreted these agreements as precluding the United Nations from requiring the IFIs to undertake specific action and as granting them, in effect, completely independent decisionmaking power on all issues ${ }^{87}$ As a result, the IFIs have felt free to reject the recommendations and decisions of not only the United Nations, but also of other specialized agencies.

Consequently, on those occasions when the IFIs, in the course of their economic responsibilities, have been compelled to address the social, cultural, educational, environmental, civil, or political aspects of their member states' affairs, they have felt free to develop their own policies on the relevant issues. With the broadening of the scope of the IFIs' activities, the number of areas in which this is occurring has grown. ${ }^{88}$ It now includes

recommendation. See Agreement Between the United Nations and the International Labour Organization, art. IV, 9 U.N.T.S. 186 (1946) [hereinafter UN-ILO Agreement]; Agreement Between the United Nations and the World Health Organization, art. IV, 115 U.N.T.S. 194 (1948) [hereinafter UN-WHO Agreement].

82. See Broches, supra note 18; Gold, supra note 60.

83. See Samuel A. Bleicher, UN v. IBRD, 24 INr'L ORC. 3 (1970); Alejandro Teitelbaum, Development: United Nations and the Bretton Woods Institutions, available from TWorldNe@SMTP (Third World Network) (notes@igc.apc.orgl (On file with authors).

84. IMF Relationship Agreement, supra note 81, at art. III; Bank Relationship Agreement, supra note 81, at art. III. Compare UN-ILO Agreement, supra note 81, at art. III; UNWHO Agreement ("the [organizations] shall include on the agenda . . . items proposed by the United Nations").

85. IMF Relationship Agreement, supra note 81, at art. V; Bank Relationship Agreement, supra note 81, at art. V. Compare UN-WHO Agreement, supra note 81, at art. V; UN-ILO Agreement, supra note 81 , at art. V ("subject to such arrangement as may be necessary for the safeguard of confidential information, the fullest and promptest exchange of information and documents shall be made").

86. IMF Relationship Agreement, supra note 81, at art. I(3); Bank Relationship Agreement, supra note 81 , at art. I(3).

87. See, e.g., Broches, supra note 18. The one exception to their position is that the $\mid \mathrm{Fls}$ appear to recognize their obligation to follow UN Security Council Resolutions, adopted pursuant to Chapter VII of the United Nations Charter. See Shihata, supra note 67, at 32.

88. There is a similar increase in the interactions between the IFIs and regional organizations which often have similar substantive areas of expertise to the universal organizations. 
security, environmental, human rights, educational, and cultural issues. For example, both the IMF and the Bank have undertaken work regarding military expenditures in member countries, on the appropriate role of the state in the national economies, and on the social safety nets required for countries undergoing economic and social transformations.

In principle, the IFIs can make one of two responses whenever their operations encroach on the jurisdiction of other international organizations. The first response is to develop an in-house capability to deal with these new issues. The Bank, for example, appears to have adopted this response in the environmental area.

The second response is to formally commit to respect and follow the binding decisions of the international organizations that have specific responsibilities in the relevant area. While, there is no legal requirement to adopt the recommendations or follow the policy guidance of other international organizations, the IFIs could publicly commit to giving serious consideration to these recommendations and guidelines. Although the IFIs have never explicitly adopted this approach, they do engage in dialogue with other international agencies and occasionally change their own policies in response thereto. For example, the IMF made some changes in its conditionality policies in light of a UNICEF study on adjustment, ${ }^{89}$ and the Bank consults regularly with the WHO on health issues. ${ }^{90}$ This dialogue occurs on an ad hoc basis and, because of their present interpretation of the Relationship Agreements, at the discretion of the IFIs.

The second response is more consistent with a world order in which all international organizations, while increasingly broadening the scope of their actions, are limited to clearly defined mandates. Moreover, in the present environment there is an obvious need for coordination that would avoid conflicting policies and unnecessary duplication of effort and expense.

There are, however, a number of potential problems with this second alternative. The first is a problem of jurisdiction: there may be more than one international organization with competence in the relevant subject matter. For example, there might be both global and regional organizations dealing with the issue under consideration. This problem is compounded by

89. See Cornia, supra note 34 .

90. See, e.g., Richard H. Demuth, Relations With Other Multilateral Agencies, in THE WORLD Bank Group, Mulitlateral Aid, and the 1970s (John P. Lewis \& Ishan Kapur eds., 1973). See also International Bank for Reconstruction and Development, Operational Directive 15.20, The faomorlo Bank Cooperative Program (May 1991); Operational Directive 15.00, Relations with Multilateral Agencies (forthcoming); Operational Directive 15.10, Relations with United Nations Acencies (forthcoming); Operational Directive 15.11, Relations with the United Nations Development Procram (forthcoming); Operational Directive 15.40 World Bankinternational Monetary Fund Collaboration (forthcoming). 
the lack of an efficient international mechanism for resolving these types of jurisdictional disputes. As a result, two agencies, both with responsibility in the relevant area, might give inconsistent advice to the IFIs. In addition, their decisions and recommendations might not be easily translated into the operationally useful standards that the IFIs need.

A second problem concerns the efficacy of the international organization: it is possible that the organization might not effectively or competently perform its own mandate. As a result, the IFIs may lack confidence in the organization's decisions and recommendations.

A third potential problem is the dangers inherent in centralization: all international organizations will begin adopting identical, or at least, closely coordinated policies. This would create an international orthodoxy on each issue that might limit the policy options available to individual countries.

These problems are not insurmountable. To limit the dangers of both an "anarchic" approach and of an overly centralized approach, the IFIs need to increase their cooperation with other international agencies. This would help avoid the problems that can be created by the IFIs' encroachment into the jurisdiction of other international organizations. ${ }^{91}$ The first step all organizations should take is to improve interagency communication. This should involve extensive and formalized exchanges of information, ideas, and expertise among the staffs of all relevant organizations. These interorganization communications should include training programs for the staffs, as well as a structured program of continual discussion on issues of mutual concern. Joint training programs could be supplemented by staff exchanges. ${ }^{92}$ Interstaff discussions should be supplemented by the incorporation of mutually useful information in their country and thematic reports. These reports should also include discussions of the relevant findings and recommendations of other international organizations. For these exchange programs to be effective, both sets of organizations should effectively involve nongovernmental actors in all discussions, and training and staff exchange programs. ${ }^{93}$

91. Other international organizations also need to respond to the intertwining of problems and the blurring of their jurisdictional boundaries. For example, environmental organizations need to incorporate the interests of workers, consumers, and the unemployed into their work. Similarly, human rights organizations need to more carefully assess how human rights fit into the development process and how they can work with the IFIs to promote a more "human rights sensitive" development process.

92. The structure of the newly established Global Environment Facility (GEF) in which the Bank, the United Nations Environment Program, and the United Nations Development Program all provide the GEF's staff might prove to be a useful model in this regard. See Instrument For the Establishment of the Restructured Global Environment faclity, Report of the Gef Participants Meetinc, March 14-16 1994 (31 Mar. 1994).

93. If NGOs are to participate effectively in these efforts, they will need to develop their own ability to respond to intertwined problems. 
In some cases, particularly in the environmental area, this dialogue is well under way. However, in the human rights area, interorganizational discussion is tentatively beginning. All the relevant international bodies should be encouraged to stimulate and participate in this type of dialogue. The increasing encroachment of IFIs into the work of other international organizations requires the IFIs to also rethink their obligations under general principles of international law. In addition to acknowledging that the Security Council Resolutions adopted pursuant to Chapter VII of the UN Charter are binding, the IFIs need to recognize evolving trends in international law and to make explicit their interpretations of international law's applicability to their fields of operation. For example, in light of the current international concern with democratization and good governance, the IFIs should explicitly state what they view as their obligation in promoting such aspects of democratization and good governance as freedom of speech and association.

\section{A PROGRAM OF ACTION}

The challenges that the IFls face are complex and will not be easily resolved. A successful response to these challenges will require the participation of all stakeholders in the work of the IFIs. The international community's ability to devise an effective strategy for dealing with these challenges is also affected by the fact that its knowledge on some of the relevant issues is rudimentary. For example, the international community has not agreed on the contents of a successful environmentally sustainable development strategy, or on an operationally useful theory concerning the indivisibility of civil, political, economic, social, and cultural rights. In addition, the international community needs to fully identify the institutional characteristics for international organizations, which are designed to effectively deal with a range of intertwined problems. ${ }^{94}$

94. Fortunately, the international community has a reasonably well-developed understanding of institutional arrangements. For example, the international community has clearly acknowledged the importance of adequate disclosures of information to, and of participation by, nonstate actors in the development process. See, e.g., Lori Udall, The World Bank's Revised information Policy and New inspection Panel: Public Accountability or Public Relations?, in Beyono Bretton Woods, supra note 32, at 45 . The need for greater coordination and structural changes among international organizations is widely acknowledged. See Erskine Childers \& Brian Urquhart, Renewinc the United Nations Srstem 77-84, 197-98 (1994); Our Global Neighborhood, The Commission on Global Governance (1995); Rethinking Breton Woods: Towards Equitable, Sustainable, ano Participatory DevelopMENT (Jo Marie Griesgraber ed., 1994); Bretton WoOds: Looking to the Future, supra note 35; Browne, supra note 32. 
Notwithstanding the need for a comprehensive approach to these issues, the authors have identified a set of measures that deal with the institutional problems identified in this article. Implementation of these measures would improve the institutional arrangements of the IFIs, generate information that might facilitate the development of a more comprehensive approach to the challenges facing the IFIs, and change both the IFIs' internal decisionmaking processes and their external relations. Therefore, the IFIs should:

** reinterpret their charters to clarify what issues are considered "domestic" political issues, and therefore outside the scope of their mandate. While this prohibition has a continuing validity in excluding undue influences, it should not prevent the IFIs and the multilateral development bank from incorporating all matters governed by international law, such as human rights and the protection of the environment, into their operations. Such a reinterpretation would facilitate efforts to promote a development process that is governed by the rule of law.

** reinterpret their Relationship Agreements with the United Nations. The IFIs should acknowledge that it is consistent with the terms of these agreements for them to publicly commit to comply with all the decisions of the United Nations. In addition, recommendations should be broadly and publicly debated. In those cases where compliance is not possible, the IFIs should promise to publicly explain their reasons.

** collect information on the international legal commitments of their borrower states and on the compliance of those states. In so doing, the IFIs should not limit themselves to the information provided by their member states with these commitments. They should also consult NGOs. The IFIs can use the terms and conditions attached to their funding arrangements to achieve this objective. For example, the Bank could make it a condition of its loans and the IMF could make it a term of its standby arrangements ${ }^{95}$ that the borrower state provide them with information on all pertinent international agreements to which it is party, on its interpretation of its obligations arising out of these agreements, and on the measures it has taken or intends to take to comply with these agreements. The IFIs could also demand copies of all reports the state makes, particularly to other international organizations, in connection with these obligations. The IFIs should then use this information to ensure that they only fund projects, policies, and stabilization and adjustment programs that promote compliance with validly assumed international obligations. For example, states that are signatories to various human rights conventions should be required to ensure that their projects and programs are consistent with their obligations under these conventions.

95. The member state could assert its willingness to provide this information in the Letter of Intent it submits to the IMF as part of its request for IMF financing. 
** publicly commit to protecting all private actors who participate in the IFIs' operations and who suffer reprisals as a result. The IFIs should make public their commitment to deny new financing requests to any state that is found to be taking reprisals against anyone who has sought to participate in the design or implementation of IFI-funded projects or stabilization and adjustment programs. In extreme cases the Bank should commit to suspend disbursements on existing loans, and the IMF to suspend purchases on existing financing facility arrangements with the member states.

** collaborate with other relevant specialized agencies and regional arrangements. This collaboration should include joint training programs and staff exchange programs. It should also involve an ongoing dialogue between the IFIs, specialized agencies, and regional organizations on matters of mutual interest. NGOs should be able to broadly participate in these programs and discussions.

** establish mechanisms for freer public participation in all aspects of their operations. These mechanisms should include:

a) the opening of decisionmaking fora to public participation. This could include allowing the public to attend some Board of Director meetings, and the meetings of the Board of Governors.

b) the establishment of a body of independent experts with broad community participation, who do not seek or receive instructions from the member states. These bodies should have the power to seek information from the IFIs' staffs, to make recommendations to decisionmakers in the IFIs, and to receive publicly disclosable explanations from the staffs or the Board for their failure to follow the advice given by the body of independent experts. A strengthened and expanded version of the IBRD's Advisory Council is an example of such a body.

c) more open administrative procedures so that the IFIs' operating rules and procedures are subject to public participation. One possibility would be to submit any proposed rule or procedure for public comment. The IFIs should be required to publicly respond to these comments.96

d) more transparent and participatory substantive policymaking procedures. This should include an opportunity for public comment on draft policies and a requirement that the IFIs explain their responses to these comments.

** develop codes of conduct for their staffs that properly recognize both their obligations to the IFIs and to all other stakeholders in their operations.

96. At present, the IFIs may informally seek out the views of nongovernmental actors on proposed policies and programs. However, this practice should be formalized and rendered transparent. 
All these measures can be achieved under the existing charters of these international organizations. ${ }^{97}$ However, these measures will require that the IFIs reinterpret their charters, using the traditional means of legal discourse for interpreting legal texts. It should be recognized, however, that because of the ongoing nature of the challenges that the IFIs face, these measures will not lead to a resolution of all the challenges facing the IFIs. Instead, these measures will create the mechanisms and the atmosphere that will allow all of the IFIs' stakeholders to participate in the debate over these issues. They will also make it possible for interested parties to hold the IFIs accountable for the consequences of their actions. ${ }^{98}$

To facilitate these changes, other international actors should also take action. The specialized agencies and regional organizations need to develop transparent and accountable governance procedures. They also need to develop operationally useful guidelines in their areas of expertise. Once this is accomplished, they can then work with the IFIs to incorporate these guidelines into the IFIs' policy and programmatic activities. This process should be complemented by an ongoing dialogue between the IFIs and these organizations. In addition, specialized agencies and regional organizations should address issues of particular interest to the IFIs in their country and thematic reports. NGOs should be invited to participate in this ongoing dialogue.

Finally, NGOs have a crucial role to play in realizing these changes in international institutional arrangements. NGOs should educate their own governments on the need for these reforms and should organize their constituents to campaign for them. Success in these efforts could create a space for even more dramatic changes than those outlined above. Ultimately, these reforms could make it possible for formal participation by nonstate actors in such international organizational issues as voting, electing officials, supervising compliance, and in developing structures for direct NGO participation in decisionmaking.

97. The authors have limited their proposals to those achievable within the existing charters of the IFIs because in the present political climate it is not likely that the international community would agree to substantially amend these charters to make the organization more democratic. Furthermore, prudence suggests that the elasticity of these charters should be fully explored before the international community embarks on the politically risky task of seeking major charter amendments.

98. Over time these changes should make it easier for interested parties to fashion an international agreement on how to achieve sustainable and equitable development and to design organizations that are capable of producing sustainable and equitable development. 


\section{CONCLUSION}

The world has changed dramatically since the time of the Bretton Woods Conference. However, the institutional structures and relations that were created at that time have not.

The IFIs have responded to this disjuncture between their actual work and their institutional arrangements with ad hoc changes in their policies and operating rules and procedures. This paper has argued that these responses are inadequate because they are not based on sound legal principles and do not promote the rule of law. The IFIs are bound by general principles of international law. They need to ensure that their actions and policies are consistent with these principles and that they help other international actors to conform their behavior to these principles. This paper has proposed a number of steps that the IFIs can take to ensure their compliance with the international legal order. If undertaken, these steps will also help promote a participatory and sustainable development process. 